\title{
FORMING A CRISIS RESOLUTION MECHANISM IN INTERNATIONAL LAW
}

\author{
MYKHAILO NAGORNIAK
}

\begin{abstract}
This article examines modern approaches to assessing the effectiveness of international legal norms, analyzes international law aspects of the use of military force, and defines the criteria of its adminissibility and legitimacy as a means of conflict resolution. It differentiates between inviolability of the state sovereignty and human rights protection in the aspect of military invasion based on humanitarian reasons. This note emphasizes that at the inception of the multipolar international system, the old legal toolkit, which dates back to the Cold War period is incapable of solving problems that arise in the 21th century. The examples provided here demonstrate that not only do the key geopolitical players ignore the current norms of international law and contractual obligations but they also manipulate the law to justify their geopolitical plans.

The more resources the countries own the more they are capable of ignoring the norms of international law, thus creating a threat to peace and security in the world. Attention is drawn to the fact that mechanism of solving crises begins to emerge outside the legal field, which leads to an imbalance between the condition of international law and the international legal order. The necessity of reforming the UN, which should be accompanied by the introduction of a number of changes in international law and the revision of the powers and functions of the International Court, is emphasized. Yet any political and legal innovations have to be considered from the perspective of the role of international law as a potential means of protecting the 'weaker' states from the 'more powerful' ones.
\end{abstract}

Keywords: International law, norms of international law, degradation of legal system, aggression, humanitarian intervention, state sovereignty, human rights, the UN Charter.

The global changes that have occurred in the world since the end of the $20^{\text {th }}$ century require the correction of the conceptual approaches to states security issues. They are usually associated with the collapse of the former bipolar system of international relations and the radical rearrangement of forces in the international arena. This approach, however, fails to analyze profoundly the disputes and international problems that had been slowed down artificially or stayed those of secondary importance during the period of the Cold War, in particular the ones considering the adequacy of international law norms to the challenges of the third millennium.

We are facing the task of determining the extent to which the international law can be viewed as a specific means of protection of the "weaker" states from the "more powerful" ones in case where actors employ overt military force in international relations.

The present international security system evolved from the ambiguous situation at the turn of the century. On the one hand we are witnessing gradual forming of a universal norm that stipulates 
responsibility of world society for observance of the basic human rights, including the right to live, but on the other hand - the employment of military forces which is seen as, according to Article 1 of the UN Charter, the only means able to prevent and eliminate the threat to peace [5].

This approach to the circumstances that established the multipolar international system allows the key geopolitical players not only to ignore current international-law norms and contractual obligations, but also to manipulate them to justify their geopolitical plans. All of the mentioned undermines the democratic, progressive and humanistic foundations of international law, which had been preserved even during the period of the Cold War.

Russian researcher I. Kuklina explains the causes of such condition: "upon the end of the Cold War, international law regulation of the preservation of peace and security along with the whole structure of international relations was shaken to its foundations" [1, p. 25]. It is clear therefore that in the conditions of the forming of new international relations system the old legal toolkit of the Cold War period could not solve the evolving problems that have emerged in the first decade of the $21^{\text {st }}$ century. The emergence of new problem solving mechanism outside the legal field attests to the ineffectiveness of international law norms concerning crises in the Arab world and in the areas of the former USSR, particularly those in the south-east of Ukraine.

Thus, the government of Russian Federation has completely ignored the norms and agreements formed on the basis of Ukrainian-Russian treaties concerning sovereignty and territorial integrity, particularly the Treaty on Friendship, Cooperation, and Partnership between Ukraine and the Russian Federation signed in May, 1997. In addition to that the Russian Federation has ignored international legal guarantees, provided to Ukraine under the Budapest memorandum when Ukraine agreed to sign the Nuclear Nonproliferation Treaty. The attempts of the USA and Great Britain, which had also signed the Budapest memorandum, to enforce international mechanism of reaction to the crisis through addressing the United Nations Security Council proved to be unsuccessful. Ukraine`s international plight not only highlights the impotence of the international security apparatus against stronger actors but also demonstrates that states have yet to develop meaningful countermeasures for hybrid warfare.

The annexation of Crimea by Russian Federation and the military support, provided for the separatists in Donetsk and Luhansk region are grave breaches of the UN Charter (p. 3 and 4, articles 2), as well as the articles of the final act of the Conference on Security and Co-operation in Europe held during July and August 1, 1975, that oblige the countries which had signed it to abstain from employing military power or threats of such, and to solve international disputes by peaceful means. Despite this all, mentioned actions were not properly assessed and reacted to by the International community.

The Russian Federation is waging a sort of "hybrid warfare" against Ukraine. The international regional and global security apparatus approach to solving this unique dilemma has been flawed and ineffective. Given such systemic failures, reforming the Organization for Security and Cooperation in Europe (OSCE) should be seriously considered. The necessity of enforcement and modernization of the European security system has been discussed for a long period now. It was demonstrated by the discussions that emerged in the context of the Corfu Process (2009) and the Helsinki +40 process (2012). The questions, raised during in the course of these discussions, were mostly about enhancing the role of the OSCE in the conflict prevention and the arms control in Europe. Under the provision of The Program of Immediate Actions that was first agreed on in Helsinki in 1992, then supplemented and developed in the Vienna document-94, the countries-participants have undertaken substantial commitments concerning the political and military aspects of security. The parties agreed that all controversial issues are to be solved by consensus, which means that the decision has to be unanimous. Since the Russian Federation is one of the participating states, Russia's refusal has impeded the effective involvement of the OSCE in the crisis regulation of Ukrainian-Russian relationship.

The current state of international affairs demonstrates that the world security institutions have failed to provided a guarantee of security to the largely predominately because the existing paradigm continues to rely on the old international legal toolkit. Indeed, despite some political analysts' 
speculations about withering away of the state in a globalized world, it remains a major and even single legal subject responsible for providing of territorial and global security [6, p. 231-238].

It should be noted that back in 1986, Prof. Carty drew scholarly attention to the ineffectiveness of international law in his book 'The Decay of International Law? A Reappraisal of the Limits of Legal Imagination in International Affairs.' In particular, he emphasized the dangerous trends that appeared in the political practice of official circles to use legal principle to legitimize both their domestic and foreign policy steps. 'The official position, - stressed scientist - is inevitably limited by unilateral interpretation of the legal principle used with a variety of "non-legal" argument, referring to the domestic audience or to specific Allied forces. Attempts to "pacify" the opponent is quite rare' [10, p. 115].

It is widely known that the development of international law was based on the UN Charter, which includes an integral right of self-defense, a rather vague doctrine of "proactive" self-defense, and the inherited state doctrine of opinio juris sive necessitates. Thus, one of the most authoritative international organization's monopoly on the use of force in international relations is enshrined in the UN Charter with only one strictly defined exception. 'All Members shall refrain in their international relations from the threat or use of force against the territorial integrity or political independence of any state, or in any other manner inconsistent with the Purposes of the United Nations [5].' Subsequently, the formula above was elaborated in the documents accepted as UN resolutions. Among them there were the following: Declaration on Principles of International Law (24 October 1970), Definition of Aggression (24 October 1970), the CSCE Helsinki Final Act of 1975 and a number of other documents in the Helsinki process as well as the Declaration on the Enhancement of the Effectiveness of the Principle of Refraining from the Threat or Use of Force in International Relations (18 November 1987). The elements of the normative content of the principle of non-use of force are: a ban on the occupation of the territory of another country in violation of the international law; a prohibition of acts of reprisals involving the use of force; granting by a State its territory to another State that uses it to carry out aggression against a third State; organizing, instigating, assisting or participating in the acts of civil war or terrorist acts in another State; the organization or promotion of armed bands, irregulars, including mercenaries, for incursion into the territory of another State. Violent actions against international demarcation lines and lines of a truce, the blockade of ports or coasts of a State, any violence that prevents people from exercising the legitimate right to self-determination, as well as several other violent acts should also be considered violations of the principle of the non-use of force.

The UN Charter stipulates (Chapter VII: Actions with Respect to Threats to the Peace, Breaches of the Peace, and Acts of Aggression) only two cases of legitimate use of armed force: the right to individual or collective self-defense (article 51) and, based on the decision UN Security Council, in case of a threat to the peace, a breach of the peace or an act of aggression (Article 42). According to these statements, the Security Council has the right to take such actions by air, sea, or land forces as may be necessary to maintain or restore international peace and security. Nevertheless, the Security Council, as in the case of the Gulf War, may delegate the implementation of the Act to a State or groups of States. However, such delegation should be entirely transparent, with Security Council reserving the functions of the control authority.

As for the exception contained in the Article 51 of the Charter, i.e. the right to self-defense in case of an armed attack on a member of the organization, international law defines self-defense as the measures which are proportionate to the armed attack and necessary to respond to it. Given the fact that international law is older than the UN Charter, this principle, as well as doctrine of self-defense, as the statute of customary law, was confirmed by the International Court of Justice in the case Nicaragua v. United States in 1986. Despite this, it is important to remember the fact that, according to Article 51 self-defense may last only "until the Security Council has taken measures necessary to maintain international peace and security".

Nevertheless, in the post-bipolar system of international relations we are witnessing, the United States openly disregarding international law and the UN Charter. Some proofs of this were the use of military force in Yugoslavia, the war in Iraq, the bombing of facilities in Pakistan, and the military 
action against Libya. In fact, the US as a hegemonic state has created a precedent that raises questions about the effectiveness and credibility of the UN and the Security Council. Prof. John B. Quigley not only speaks about the threat of the Security Council becoming a helpless hostage of the US geopolitical ambitions, but also gives four types of situations that reflect the inability of the Security Council to properly perform its functions primarily as a result of the dominance of the United States. First, in situations of "threats to peace" the United States reported dubious facts before the Security Council reported them, and the Council acted as if the alleged facts were true without conducting its own investigation. Second, in many cases, the United States acted on the basis of powers granted to the Security Council, but without any actual decisions taken. Third, the United States in several cases urged the Security Council to authorize them to resort to military action unilaterally, and not under the control of the Council. Fourth, the United States, using the power of veto prevented the carrying out of the settlement of the most prolonged territorial dispute in the history of the UN, the dispute between Israel and Palestine [15, p. 130].

As demonstrated by international experience, the leading countries of the world are not primarily guided by the principles and norms of international law, but rather by their geopolitical interests. In our opinion it is in line with their geopolitical interests that the mechanism of crisis resolution in the world began to form. The turning point for the entire international legal system was the US reaction to the decision of the International Court concerning Nicaragua on 15 April 1986. That's when the United States, ignoring the decision of the International Court, after obtaining the consent of Margaret Thatcher to use the UK as a transit point for their bombers, attacked five targets on Libyan territory. Then the US attempted to somehow justify their actions, which found practical expression in the 15 January 1986 speech of then-Secretary of the State George Shultz at the University of National Defense. In his speech he said: 'It is absurd to argue that international law prohibits us from capturing terrorists in international waters or airspace; from attacking them on the soil of other nations, even for the purpose of rescuing hostages; or from using force against states that support, train, and harbor terrorists or guerrillas. [...] A nation, attacked by terrorists is permitted to use force to prevent or preempt future attacks, to seize terrorists or rescue its citizens when no other means is available.' [7, p. 204]. In order to achieve its objectives, the United States abstained from voting on the UN Security Council resolution, which condemned the use of force by Israel against the Palestinian Liberation Organization, committed in the territory of Tunisia in 1985. This action was condemned by the Security Council 'as flagrant violation of the Charter of the United Nations, international law and norms of conduct'. [20]. Explaining the US position on this issue, the head of the US delegation Walters extended to the Government of Tunisia "sincere condolences over the loss of life of its citizens" [20].

Trying to give international legal assessment of the use of US military power abroad, prof. J. Paust asked in 1986: 'is it permissible under international law to attack terrorists on the soil of another nation without the consent of such a nation-state? Indeed, is it permissible to attack states that support, train or harbor terrorists?' [14, p. 714]. After analyzing the UN Charter, the 1970 Declaration of International law and many other authoritative opinions (the overview takes up around two pages of footnotes), that condemn both preemptive and retaliatory reprisals, J. Paust comes to a conclusion: 'implementation of the "Schultz doctrine" by the use of preemptive or retaliatory use of force would place the United States in violation of international law and must be opposed' [14, p. 719].

It should be noted that, in seeking answers concerning the legality of the US actions, Paust did not set out to denounce them. On the contrary - he seems to confirm their legitimacy. The scholar, however, clearly did not want to take a position, which would have made it impossible for the United States to respond to a terrorist threat. In the same article he states: 'Situations may arise when the use of force is reasonably necessary to assure an overall serving of the purpose of the Charter [UN], but the circumstances would have to be compelling and the actual use of force would have to be reasonably necessary and proportionate and not otherwise involve an impermissible targeting of individuals or objects. [14, p. 307, 310]. Analyzing the official explanation of the US actions, the scholar found them extremely controversial. Thus, according to the information published in New York Times, this raid was seen first as retaliation for a prior terrorist attack in Berlin [18], then 'mainly a signal to Colonel 
Gaddafi to cease terrorist acts' [17], then as an attempt to intimidate the elite Libyan guard which Gaddafi saw as a support [12], and also as a measure of self-defense in response to attacks on American citizens and American embassies, which had occurred earlier [19]. This led J. Paust to an informed and careful conclusion that the Us action 'was highly questionable' under international law [14, p. 732].

Given previous experience, S. Biddle, the colleague of Paust, referring to the 1999 operation "Allied Force" against Serbia, which lasted for 78 days, in the review prepared for the "Foreign Affairs", decided to avoid all mention of international law and the United Nations [8, p. 138]. Instead the concept of the necessity to avert humanitarian disaster as a justification for the military operation became increasingly popular both among the officials and among the experts. This argument, which was used to justify the intervention of the Allied Powers in the internal affairs of the former Yugoslavia, has become quite attractive in terms of morality, because it made the criticism of this action by third states virtually impossible.

At this time a new concept of "humanitarian intervention" emerged in the field of politics and law and quickly became part of political rhetoric. Despite the existent interpretations of the term in the writings of CIS scholars V. M. Barynkyn, T. V. Bordachev, I. G. Vorobyov, E. Y. Guskova, I. N. Manzhuryn, G. M. Mikhailov, S. A. Romanenko, A. A. Hohlysheva, A. V. Hudaykulova, S. V. Chernichenko and in the writings of Western scholars T. Bothem, T. Woodhouse, J. Donnelly, F. Ebyu, R. Keohane, A. Ramsbothem, S. Thomas, J. Holtshrif, D. Schaeffer and otherset. al., the question of eligibility and reasonableness of this intervention remains open. Along with the countries that supported such an operation, a number of countries opposed [2]. The difference in the positions of members of the NATO confirms that humanitarian intervention cannot be regarded as a universal mechanism for resolving crises.

At that time the US tried to generate a conceptual framework for a new mechanism of resolving crises, which establishes the right to interfere in the internal affairs of a state to protect the rights of the civilian population of this state; that framework will eventually create a precedent for interference of Russian federation in the internal affairs of Georgia and later Ukraine. Yet such a mechanism for resolving crises in the world does not take into consideration two major premises of international law: human rights, monitoring their compliance by the international community, and state sovereignty, the principle of non-interference in its internal affairs. Thus, it is based on disregard of fundamental rules of international law, since the concept of sovereignty proclaims the principle of non-interference in the domestic affairs of a sovereign state and therefore any use of government forces, according to the UN General Assembly Resolution 1947, qualifies as an act of aggression [3, p. 3-5].

However, to avoid such charges, geopolitical players refer to the fact that in the context of democratization of international relations, freedom of action of a sovereign state on the world stage should be limited in a number of important issues and subject to control by the international community, just as absolute power of the sovereign - the monarch or the people - within the state should be limited, conditional by certain circumstances and always be accountable [9, p. 14]. On the surface, the following considerations could be accepted, because sovereignty includes both external and internal components. According to the Russian researcher R. Oreshkina, "the value of sovereignty is not obvious, unless it is seen as an instrumental good, that is, as a means of achieving more fundamental goals, so a large-scale violation of human rights is not only apparent disregard for human dignity, but also disregard the principle of sovereignty" [4, p. 10].

According to such logic, large-scale violations of human rights de-legitimize state sovereignty both internal and external, therefore that could legally justify humanitarian intervention. However, despite the current trend of democratization and globalization one cannot ignore the differences among the states' interests and therefore different perceptions of sovereignty. For the developed countries under the influence of globalization, sovereignty loses its meaning. For poor countries, the situation is different as emphasized by D. Reiff when he posits, "Sovereignty remains the best defense against foreign hegemony" [16, p.116]. Accordingly, the scientist believes that the intervention in the affairs of sovereign states, "regardless of lack of interest or new UN mandate or international law, is a colonial activity" [16, p. 117]. In addition, he is against "global understanding of human rights" [16, p. 118]. 
Such considerations suggest that study of these complex issues should not be taken to extremes; one ought to take balanced approach to the analysis of the processes occurring in the world, considering the state of international law. Without delving into the theory of law, we should however recognize that, despite all the different ways of its development, international law is largely formed under the influence of powerful international players. C. Chinkin, criticizing the war in Kosovo, states: 'Finally, the Kosovo intervention shows that the West continues to script international law, even while it ignores the constitutional safeguards of the international legal order (...). All these incidents serve to undermine the Charter (...). The case of Kosovo may have highlighted the continuous chasm between human rights rhetoric and reality. It does not resolve the way this can be bridged' [11, p. 846-847]. The expressed opinion is quite important because an expert draws attention to the dangers which may arise in case of violation of the delicate balance between the state of international law and the international legal order.

Therefore, "hybrid warfare" waged by Moscow today, highlighted another problem of the third millennium: the more resources the great powers have, the more they are able to ignore international law and their obligations, creating a threat to peace and security in the world.

Another obvious fact is that European countries, faced with the unpredictable behavior of the Kremlin, have become hostages of the imperfect system of regional security, and therefore realised the need for such a security system in Europe that would be based on the principles of "safety of development", the collective regulation of conflicts and conflicting situations, and the establishment of mechanisms for collective preventive intervention in the conflict. The new architecture of European security must be organized in such a way that the control of arms, military technology, and the use of the armed forces was placed under wide "collective sovereignty", which should be granted to the OSCE.

Moreover, given the significant role of the new geopolitical players, it is clear that the Security Council, its composition and functions today require democratic reform. In our opinion, such a reform should be accompanied by the introduction of a number of changes to international law and the revision of the powers and functions of the International Court. Granting new functions to the Court ought to provide this international institution with the opportunity not only to review the decisions of the Security Council regarding the possible threats or breaches of international peace and security, but also with specific powers for the protection of the Security Council.

Therefore, any political and legal innovations in the functioning and status of this reputable organization should be analyzed while keeping in mind the place and role of international law as a potential remedy "weak" states the pressure "strong".

\section{REFERENCES}

[1] Куклина И. Глобальное обеспечение безопасности: коллапс силы и права? Мировая экономика и международные отношения, 3 (2013), 2-28.

[Kuklyna Y. Hlobalnoe obespechenye bezopasnosty: kollaps sily i prava? Myrovaia ekonomyka y mezhdunarodnye otnoshenyia, 3 (2013), 2-28.]

[2] Мартынов Б.Ф. (Ред.) Мир после Косово: Россия, СНГ, Латинская Америка: материалы науч.практ. конф. ИЛА РАН., М., 2000, 150.

[Martynov B.F. (Ed.) Myr posle Kosovo: Rossyia, SNG, Latynskaia Ameryka: materyaly nauch.-prakt. konf. YLA RAN., M., 2000, 150.]

[3] Определение агрессии: Резолюция Генеральной Ассамблеи ООН: принята 14.12.1974 г. на 29-й сессии Генеральной Ассамблеи ООН. В: Бекяшев К.А., Ходаков А.Г. (Сост.) Международное публичное право, сб. док. в 2 т, Т. 2. БЕК, М., 1996, 3-5. 
[Opredelenye ahressyy: Rezoliutsyia Heneralnoi Assambley OON: pryniata 14.12.1974 h. na 29-y sessyy Heneralnoi Assambley OON. In: Bekiashev K.A., Khodakov A.H. (Eds.) Mezhdunarodnoe publychnoe pravo, sb. dok. v 2 t, T. 2. BEK, M., 1996, 3-5.]

[4] Орешкин Р.В. "Гуманитарная интервенциия" в общей внешней политике и политике безопасности Европейского союза в 90-е гг. ХХ века, автореф. дисс. на соискание науч. степени канд. ист. наук. Волгоград, 2005.

[Oreshkyn R.V. "Humanytarnaia ynterventsyia" v obshchei vneshnei polytyke y polytyke bezopasnosty Evropeiskoho soiuza v 90-e hh. XX veka, avtoref. dyss. na soyskanye nauch. stepeny kand. yst. nauk. Volhohrad, 2005.]

[5] Статуm Організації Об'єднаних Націй. Виданий Департаментом інформації ООН. Електронний ресурс. Режим доступу: unic.un.org./aroundword/unic.

[Statut Orhanizatsii Obiednanykh Natsii. Vydanyi Departamentom informatsii OON. Available at: unic.un.org./aroundword/unic.]

[6] Цыганков П.А. Теория международных отношений, учебное пособие. Гардарики, М., 2006.

[Tsyhankov P.A. Teoryia mezhdunarodnykh otnoshenyi, uchebnoe posobye. Hardaryky, M., 2006.]

[7] Biddle S. The New Way of War? Debating the Kosovo Model. Foreign Affairs, May-June (2002), 138.

[8] Bumgardner J. Altruism or Self-interests: What Prompts Humanitarian Military Intervention.

[9] Carty A. The Decay of International Law: A Reappraisal of the Limits of Legal Imagination in International Affairs. Manchester University Press, Manchester, 1986.

[10] Chinkin C.M. Kosovo: A “Good" or "Bad" War? American Journal of International Law, 93 (4) (1999), 846.

[11] Chose Targets to Fuel Coup Against Kadafi, Schultz Says. New York Times, 16 April (1986).

[12] Idem. Conflicting Norms of Intervention: More Variables for the Equation. Georgia Journal of International and Comparative Law, 13 (1983), 307, 310.

[13] International Legal Materials, 25 (1986), 204.

[14] Paust J.J. Responding Lawfully to International Terrorism: The Use of Force Abroad. Whittier Law Review, 8 (1986), 719.

[15] Quigley J. The United Nations Security Council: Promethean Protector or Helpless Hostage? Texas International Law Journal, 35 (2002), 130.

[16] Rieff D. On the Wishful Thinking of Eminent Persons: The Independent Commission's Kosovo Report. Human Rights Journal, 1 (1) (2002), 116.

[17] US Aides Deny Attack Is Start of an Escalation S Aides Deny Attack Is Start of an Escalation. New York Times, 16 April (1986).

[18] US Calls Libya Raid a Success. New York Times, 16 April (1986).

[19] US Defends Raids Before UN Body. New York Times, 16 April (1986).

[20] US Mission to the UN. Press Release, 4 October, 85 (106) 1985.

Address: Mykhailo Nagorniak, Vasyl Stefanyk Precarpathian National University, 57, Shevchenko Str., Ivano-Frankivsk, 76025, Ukraine.

E-mail: cpodp@mail.ru.

Received: 20.07.2017; revised: 18.09.2017.

Нагорняк Михайло. Формування механізму вирішення кризових явищ у міжнародному праві. Журнал Прикарпатського університету імені Василя Стефаника, 4 (2) (2017), 26-33.

У статті досліджено новітні підходи до оцінки ефективності дії норм міжнародного права, проаналізовано міжнародно-правові аспекти використання військової сили, визначено критерії 
допустимості і правомірності іï застосування при вирішенні конфліктів. Проведено розмежування між непорушністю державного суверенітету та захистом прав людини в аспекті використання державами збройного втручання з гуманітарних причин. Наголошено, що в умовах становлення багатополярної міжнародної системи старий нормативно-правовий інструментарій періоду холодної війни не здатний розв' язати проблеми, що з'явилися на початку XXI століття. На прикладах показано, що ключові геополітичні гравці не тільки ігнорують чинні міжнародно-правові норми і договірні зобов'язання, а й вдаються до маніпудювання ними для виправдання своїх геополітичних планів. Зазначено, що, чим більшими ресурсами володіють великі держави, тим більше вони здатні нехтувати нормами міжнародного права і своїми зобов'язаннями, створюючи загрозу для миру та безпеки в світі. Звертається увага на початок формування механізму вирішення кризових явищ у світі поза межами правового поля, котрий веде до порушення рівноваги між станом міжнародного права і міжнародним правовим порядком. Наголошено на необхідності реформування ООН, яке має супроводжуватись введенням цілої низки змін у міжнародне право та переглядом повноважень i функцій Міжнародного суду. Проте будь-які політичні і правові інновації в роботі і статусі цієї авторитетної організації мають розглядатися 3 позиції місця та ролі міжнародного права як потенційного засобу захисту “слабших" держав від “сильних".

Ключові слова: міжнародне право, міжнародно-правові норми, деградація права, агресія, гуманітарні інтервенції, державний суверенітет, права дюдини, Статут ООН. 